$\xi=-1$

\title{
Does Flow Experience Really Matter among Hotel Employees in Sarawak?
}

\author{
Mark Kasa $^{1}$, Zaiton Hassan ${ }^{2}$, Azizan Yatim ${ }^{3}$ \\ ${ }^{1}$ Universiti Malaysia Sarawak, Kota Samarahan, 94300 Sarawak, Malaysia \\ ${ }^{2}$ Universiti Malaysia Sarawak, Kota Samarahan, 94300 Sarawak, Malaysia \\ ${ }^{3}$ Centre for Pre-U Studies, UCSI University Sarawak campus, Malaysia \\ * Corresponding author E-mail: markyek@yahoo.com
}

\begin{abstract}
Studies on flow in the Malaysian hotel context are still very limited even though it is an important psychological phenomenon toward developing human resources. This present study aims to investigate the role of flow experience as a mediator between the causes of burnout and its outcomes (turnover intention and work-family conflict) among the hotel employees in Sarawak, Malaysia. In the hotel industry, which has a highly demanding working environment, employee burnout would eventually lead to turnover intention and workfamily conflict (WFC). To minimize these causes and outcomes, flow is hypothesized as a possible mediator in this study. The data were collected from 210 full time hotel employees, selected by random sampling method, and analyzed using SPSS version 20 and PROCESS version 2.11. The findings revealed that flow played a direct and indirect significant role between the causes of burnout and its outcomes. The findings suggest flow to be an important approach in alleviating the effects of burnout - turnover intention and work-family conflict.
\end{abstract}

Keywords: Burnout; Flow; Hotel; Turnover Intention; Work-Family Conflict

\section{Introduction}

Tourism industry has become one of the contributors in the economic growth of Malaysia's gross national product. Hotel operators and management should seriously consider to further enhance and developing this industry by producing quality employees in their operations. One of the ways for hotel employers to contribute to the plan is to have quality employee that are motivated, passionate, and driven to serve hotel guests. One aspect that they could look into is by encouraging their employees to experience flow in completing their daily tasks.

Hotel employees work in night shifts, irregular schedule (1) as well as low pay, unstable, and seasonal employment; all of which make a career in hotels seem unattractive (2). In addition, unstable and uncertain work settings have been suggested to correlate with turnover intention, which is a serious problem for human resource management (3). Previous studies mentioned that employees that are deeply engaged in very complex and challenging work setting, which would require them to utilize their talents and strength, tend to be eager to unleash other potential new skills to perform the tasks in enjoyable and motivating manner (4). From the above findings, this present study will determine whether flow has a significant influence on turnover intention among hotel employees in the eastern context.

\section{Literature Review}

\subsection{Flow}

Flow is defined by Csikszentmihalyi (5) as a state of deep concentration and absorption of an individual in an activity done with passion and excitement. Flow experience were related to need of achievement and predicated leading to better work performance and positive affect on work (6). As such, flow has a high potential to become an important aspect to the workforce, as it contributes to higher work productivity, innovation, employee development (7). Kasa and Hassan (8) mentioned that the positive mood induced by flow can generate creativity and positive thinking. To put it simply, employees who experience flow would be totally immersed with completing their task as it is seen as something that is genuinely worthwhile and truly beneficial for them.

Although flow is important in the organization, there is still lack of research on the role of flow among the hotel employees in Malaysian context; Sarawak. At present, a limited amount of known studies used flow in the context of Malaysian hotel employees, which were conducted by Kasa \& Hassan (9-11). Of these three previous studies, only one study, Kasa \& Hassan (10) which looked at flow as a mediator between exhaustion and WFC and between disengagement and WFC. The results of that particular study suggested that flow does act as a mediator between the variables. Apart from Kasa \& Hassan (10), there is no other known research that used flow as the mediator among hotel employees. This current study was conducted to fill this knowledge gap.

\subsection{Work-Family Conflict \& Burnout}

Being engaged and concentrating deeply whilst performing certain tasks may lead to WFC (12). WFC is known as an inter-role conflict and occurs when there is an incompatibility of the role demand stemming from other demands (family or work) which bring a negative impact to the employee (13). Numerous studies also revealed that in the hotel setting in Western country; night shift working hours and irregular working schedule were consistently correlated to a variety of negative outcomes $(1,14,15)$. Byron (16) 
suggested that future research to look into the relative importance of flow as antecedent towards WFC, which led to the objective of this study.

Burnout is a psychological syndrome (17), and may emerge when employees are exposed to a stressful working environment with high job demands and low resources (18). Burnout was found to be negatively correlated with flow in a study conducted among 831 employees of an employment agency in the Netherlands (19). Though the current study also investigated the impacts of burnout, it adds to the body of knowledge by investigating the influence of burnout as an antecedent towards the experience of flow in the demanding hotel industry.

\subsection{Conceptual Framework and Research Hypothesis}

The proposed conceptual framework (presented in Figure 1) is underpinning from the Conservation of Resources (COR) Theory. The underpinning theory (COR) justifying that work situation threatens a person's resources (health care, psychological workrelated well-being, other domains of life) while individuals are motivated to obtain, retain, foster or even to protect the resources that they value the most (20). In this present study, burnout possess a threat to the employees and the organization, thus resulting in the resource loss; resources may come in term of objects, conditions such as status or parental role, personal resources (resources that buffer against stress) and energy resources such as money, time and knowledge. By including flow as a mediator in COR model, the resources may be conserved, which would benefit employee and the organization. The forefather of flow research, Csikszentmihalyi (4), mentioned that through flow experience in the workplace, people would gain "intrinsic rewards that encourage persistence" and provide benefits. Therefore, the flow phenomena plays an important role in the workplace because the experience of flow is associated with achievement of which may increase in job satisfaction and accomplishment characteristic in the workplace as well as enhancing abstract well-being happiness and positive effect (8). Based on the explanation with regard to conservation of resources theory, the present research framework in Figure 1 was constructed.

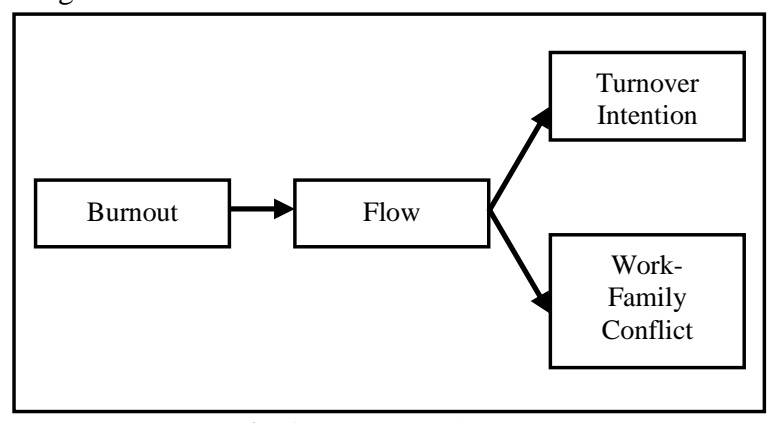

Fig. 1: The Research Framework

The construction of $\mathrm{H}_{1}$ is based on that the fact that flow is closely identical to job engagement (21). Job engagement was found to be correlated with customer satisfaction and turnover intention of employee (22) as well as correlated with motivated employees, well-being of employees and possibility of having the intention to quit from the firm (23). Nevertheless, there is a lack of understanding on the relationship between flow experience and turnover intention, which leads to the proposed hypothesis: $\mathrm{H}_{1}$ : Flow is negatively correlated with turnover intention.

With an increasing emphasis on positive psychology (24), positive experience such as flow have become a focus point of research. As flow share the same construct as job engagement, and based on some past research studies, there were negative correlation between job engagement and WFC (25). We assume that there is a negative relation between flow and WFC. Thus, the following hypothesis is proposed: $\mathrm{H}_{2}$ : Flow is negatively correlated with work-family conflict.
To the best of our knowledge, there is no known previous study of flow in a mediating role between the burnout and turnover intention. The past study that is almost similar was one that is conducted on the mediation role of job engagement between dimension of burnout and turnover intention among employees of services sector (26). Therefore, $\mathrm{H}_{3}$ is proposed due to the lack of knowledge in the literature on how flow mediates the relationship between burnout and turnover intention.

An exhaustive review of literature found no known previous studies that investigated on the role of flow as mediator between the burnout and WFC. Past studies highlighted the need to conduct this study and only found limited evidence with regards only to job engagement as mediator between job resources and positive motivational consequences (17), organizational commitment, (27), as well as work-unit innovativeness and self-initiative (28). Consequently, this literature review leads to the formulation of $\mathrm{H}_{4}$ : Flow mediates the relationship between burnout and WFC.

\section{Research Methodology}

The research instruments (summarized in Table 1) were included in self-administered questionnaires were adopted based on past literature. The questionnaires were conveniently distributed at two reputable hotels in Sarawak. There were approximately $350 \mathrm{em}-$ ployees working in the hotels. The respective hotels' human resource managers helped with the dissemination and collection of the questionnaires. The sample size was calculated using *GPower 3.1.9.2 with output parameter of actual power of 0.999. This study utilized quantitative method involving descriptive statistics and inferential statistic utilizing PROCESS (29).

Table 1: The Research Instruments

\begin{tabular}{|c|l|c|l|c|}
\hline & $\begin{array}{c}\text { Instru- } \\
\text { ments }\end{array}$ & $\begin{array}{c}\text { Number } \\
\text { of Items }\end{array}$ & \multicolumn{1}{|c|}{ Sources } & $\begin{array}{c}\text { Cronbach } \\
\text { Alpha (a) }\end{array}$ \\
\hline $\mathbf{1}$ & Flow & 13 & WOLF; Bakker (2008) & 0.87 \\
\hline $\mathbf{2}$ & Burnout & 16 & $\begin{array}{l}\text { OLBI, Demerouti, } \\
\text { Mostert, and Bakker } \\
(2010)\end{array}$ & 0.85 \\
\hline $\mathbf{3}$ & $\begin{array}{l}\text { Work- } \\
\text { Family } \\
\text { Conflict }\end{array}$ & 9 & Carlson et al. (2000) & 0.84 \\
\hline $\mathbf{4}$ & $\begin{array}{l}\text { Turnover } \\
\text { Intention }\end{array}$ & 4 & $\begin{array}{l}\text { Kelloway, Gottlieb, and } \\
\text { Barham (1999) }\end{array}$ & 0.76 \\
\hline
\end{tabular}

A total of $210(52.5 \%)$ valid questionnaires out of 400 distributed questionnaires were collected. In pilot study phase, all data (120 cases) was screened for normality and outlier testing (Mahalanobis distances; p1<.05) as well as validity (Exploratory Factor Analysis Principal Component Method), loading factor of exceed 0.5 were retained, and Cronbach's Alpha coefficient value exceed 0.70. No major issue was found at this stage and is acceptable for purpose of inferential statistical analysis. To examine the mediating effect, bootstrapping method was utilized because this method is valid and more powerful to test the indirect effect $(30,31)$.

\section{Results and Findings}

\subsection{Demographic Data}

In terms of gender, the majority of respondents are the female (53\%) whilst $46 \%$ were male. Age-wise, $(48 \%)$ are between 21 to 29 years old. For marital status, most of the respondents were single (67\%). Bachelor Degree holders were the highest with $48 \%$ and most respondents never bring work back to home $(52.39 \%)$ from the total of 210 respondents.

\subsection{Hypothesis Testing \& Discussion}

A Pearson product-moment correlation was utilized to test $\mathrm{H}_{1}$ and $\mathrm{H}_{2}$ and the results are seen in Table 2: 
Table 2: Hypotheses Testing for Direct Correlation

\begin{tabular}{|l|l|c|c|c|}
\hline & & $\mathbf{1}$ & $\mathbf{2}$ & $\mathbf{3}$ \\
\hline $\mathbf{1}$ & Flow & 1 & & \\
\hline $\mathbf{2}$ & Turnover Intention & $-0.551^{* *}$ & 1 & \\
\hline $\mathbf{3}$ & Work-Family Conflict & $-0.443^{* *}$ & $0.308^{* *}$ & 1 \\
\hline
\end{tabular}

$\mathrm{H}_{1}$ Flow is correlated with turnover intention - is supported and shows that there is a negative relationship between these flow and turnover intention $[\mathrm{r}=-.551, \mathrm{n}=210, \mathrm{p}=0.000]$. This result suggests that flow would reduce the turnover intention.

$\mathrm{H}_{2}$ Flow is correlated with WFC is supported and shows that there is a negative relationship between flow and WFC $[\mathrm{r}=-.443, \mathrm{n}=$ $210, p=0.000]$. This result suggests that flow would reduce WFC. In order to test for mediation between the variables, as described by Preacher \& Hayes' (29) approach through SPSS macros which facilitate estimation of the indirect effect in mediation model as well as a bootstrap approach in order to obtain the confidence intervals (32). The significant value should be above zero or positive value (>0 / + value) and the bootstrap upper and lower bound value, must be above zero or positive value $(>0 /+$ value $)$ in order to be determined as the significant of indirect relationship between the variables determine the significant value, as recommended by Preacher \& Hayes (29).

$\mathrm{H}_{3}$ proposed that flow mediates the relationship between burnout and turnover intention. It is supported by the regression-based analyses through bootstrapping output that flow is significantly mediated the relationship between burnout and turnover intention at $0.0950 * *$ (LLCI 0.0049 , ULCI 0.2056).

$\mathrm{H}_{4}$ proposed that flow mediates the relationship between burnout and work-family conflict. Statistically supported that flow is significantly mediated the relationship between burnout and WFC at 0.0516** (LLCI 0.0001, ULCI 0.1310).

\begin{tabular}{|c|c|c|c|c|c|}
\hline Variables & $\begin{array}{l}\text { Di- } \\
\text { rect }\end{array}$ & $\begin{array}{c}\text { Indi- } \\
\text { rect }\end{array}$ & Total & $\begin{array}{l}\text { Lower } \\
\text { Limit } \\
\text { (LLCI) }\end{array}$ & $\begin{array}{c}\text { Upper } \\
\text { Limit } \\
\text { (ULCI) }\end{array}$ \\
\hline $\begin{array}{l}\text { Turnover In- } \\
\text { tention }\end{array}$ & $\begin{array}{c}0.34 \\
4\end{array}$ & 0.950 & 1.294 & 0.0049 & 0.2056 \\
\hline WFC & $\begin{array}{c}- \\
0.07 \\
1\end{array}$ & 0.052 & -0.012 & 0.0001 & 0.1310 \\
\hline TOTAL & $\begin{array}{c}0.07 \\
3\end{array}$ & 1.002 & 1.282 & & \\
\hline
\end{tabular}

As seen in Table 3, the number of lower limit and upper limit of turnover intention was .0049 and .2056, WFC was .0001 and .1310. A value of zero (0) did not appear in the $95 \%$ confidence, which means that flow is mediated between burnout and turnover intention as well as burnout and WFC. Thus, the hypotheses are statistically proven and hypothesis $\mathrm{H}_{3}$ and $\mathrm{H}_{4}$ are accepted.

\section{Discussion and Implications}

It is concluded in this study's findings is similar with findings made by Du Plooy \& Roodt (33), Simon \& Buitendach (34), and Robyn \& Du Preez (35), where flow and job engagement, the nearest construct to flow (21), is negatively correlated to turnover intention. This in turn would lead to a motivated workforce, improved employee well-being, and reduced the likelihood of employees having the intention to leave the organization $(17,23)$.

Based on the empirical evidence discovered from Western countries, night shift working hours and irregular working schedule were consistently correlated to a variety of negative outcomes such as exhaustion, work-family conflict, and intention to quit $(1,36)$. A past study in Malaysia revealed that being too engaged in work activities may result in a form of work-family conflict (12). However, in this present study, the findings suggested that hotel employees who experience flow are unlikely to face the WFC phenomena. Flow enables them to concentrate more on their work and their priority is to feel positive about their job. As the majority of this study's respondents are single, young at age, and never bring work home, it may result in this particular find. This finding is concurrent with findings made by Kristen (37) and Macey \& Schneider (25), who stated that highly-engaged employees and WFC are negatively correlated.

The findings revealed that flow mediated the relationship between burnout and turnover intention. In previous studies, job engagement is claimed to be related to the individual's intention, attitudes and behavior (38), which have impact on employee retention (39). Additionally, job engagement is also viewed as the highest hierarchy of devotion of employees toward performing the job through the application of maximum effort for personal achievement and organizational success (26). Therefore, the reason for significant result is because of the factor such as "dedicational approach" that being utilized and the level of amount of absorption phenomena of the employee is in (40). To sum up, the experience of flow among the hotel employees has a mediating influence between burnout and turnover intention as the hotel employees could still experience flow even when they have the symptoms of burnout. Characteristic of hotel work is to deliver high quality services are rendered with the main attention toward customer satisfaction and customer loyalty $(41,42)$. Most of the employees from this study are from the generation $\mathrm{Y}(48 \%)$, which are known for their seriousness when it comes to performing tasks of their preference and a generation of new confidence, upbeat and full of self-esteem (43).

Lastly, it is statistically reported that flow mediated the relationship between burnout and WFC. Based on past studies, one of the possible reasons for the significant result is due to personality characteristics of each individual employee in the hotel industry. A previous study revealed that personality characteristics influenced the ability of individual interpretation, perception and responses toward what happen will happen next, either in personal or organizational matters (44). In this present study, the hotel's employee's personality characteristics, such as needs and wants, motives and values, as well as individual career preferences, are negatively related to individual behavioral outcomes, such as motivation, engagement, poor work performance, job stress, and high turnover (45-48). Thus, the employee perceive the need to focus and being absorbed in performing their task as their ultimate aim despite experiencing burnout though this phenomena does not conflict with their family life. As the majority of the participants in this study were single $(67.61 \%)$ and may have limited responsibility at home compared to married employees, the significant result could be attributed to the personality characteristics of the hotel employees.

In terms of mediation of flow between burnout and turnover intention and WFC, the findings from this study are exceptionally important and provide new insight to the hotel operators. By promoting and encouraging flow experience in hotel's work setting; hotel operators should consider setting clear, realistic and transparent goals, and giving them immediate feedback to ensure that their employees feel that they can manage and complete their tasks. Another way to promote flow is by limiting excessive over controlling and monitoring on the hotel's employees, which would ensure the employees feel even more empowered. In addition, hotel operators should ensure the employees skills are matched to the level of difficulty or challenges of the task in order to avoid boredom and feel frustrated or give up (4). This balance is vital because it would ensure that the employees' tasks and challenges are appropriate to the employees' skills.

The study's sample size is limited to only total of 210 respondents, which is doubtful to represent a wider population, even though the response rate $(52 \%)$ is considered sufficient and valid for data analysis. Secondly, the basis of this study is still back to human perception that does not always accurately reflect the actual feeling of flow. Hence, it is totally based on the respondent's subjective perception to identity the flow experience, burnout phenomena as well as turnover intention and work family conflict situation, a longitudinal research design may employed to study 
the pattern of relationship. Future study could be conducted to investigate on other different position levels and departments in the hotel such as administrative or operation department.

\section{Conclusion}

Hotel management should be taking drastic approaches to cultivate flow experience among the hotel employee to contribute toward achieving the organizational goals. Furthermore, cultivating flow experience as one of the strategies could retain employees in hotel industry. The crucial point to take note from this study is that if the flow phenomenon occurs among the employees, it unlikely for the employees to have the intention to quit and there is unlikely possibility for work to interfere with family matters, even though they are experiencing burnout.

\section{References}

[1] Akerstedt T, Ingre I, Borman J-E, Kecklund G. Distributed sleep in shift workers, day workers and insomniacs. Chronobiol Int. 2008;25:333-48

[2] Alan SZR, Radzi MS, Hemdi MA. An empirical assessment of hotel managers turnover intentions: The impact organizational justice. J Tour Hosp Culin Arts. 2009;1-29.

[3] Tanke ML. Human Resources Management for the Hospitality Industry. 2nd ed. Delmar: Thomson Learning; 2001.

[4] Csikszentmihalyi M. Good Business, Leadership, flow, and the making of meaning. USA: Penguin Books; 2003.

[5] Csikszentmihalyi M. Flow: The Psychology of Optimal Experience. New York: Harper and Row; 1990.

[6] Csikszentmihályi M. Finding flow. The psychology of engagement with everyday life. New York: Basic Books; 1997.

[7] Csikszentmihalyi on flow [Internet]. TED Conferences LLC Available from: http://www.ted.com/talks/mihaly_csikszentmihalyi_on_flow.html.

[8] Kasa M, Hassan Z. Antecedent and consequences of flow: Lessons for developing human resources. Procedia - Soc Behav Sci. 2013;97:209-13.

[9] Kasa M, Hassan Z. Burnout and Flow with Moderating Effect of Individualism / Collectivism. A Study in Malaysian Hotel Industry. Procedia - Soc Behav Sci [Internet]. 2016;219(May):416-23. Available from: http://dx.doi.org/10.1016/j.sbspro.2016.05.063

[10] Kasa M, Hassan Z. Burnout Dimensions with Work-Family Conflict among Hotel Employees: Flow Experience as Mediating Role. J Manag Mark Rev. 2017;2:1-7.

[11] 11. Kasa M, Hassan Z. Flow Experience and Organizational Citizenship Behaviour among Hotel Employees: Moderating Effect of Socio-Cultural Factor. Procedia - Soc Behav Sci. 2016;224:101-8.

[12] Noor NM. Work-family conflict, locus of control, and women's well-being: test of alternative pathways. J Soc Psychol. 2002;142:645-62

[13] Greenhaus JH, Beutell NJ. Sources of conflict between work and family roles. Acad Manag Rev. 1985;10(1):76-88.

[14] Demerouti E, Bakker AB, Butlers AJ. The loss spiral of work pressure, work-home interference and exhaustion: Reciprocal relations in a three-wave study. J Vocat Behav. 2004;64:131-49.

[15] Takahashi M, Tanigawa T, Tachibana N, Mutou, K. Kage Y, Smith $\mathrm{L}$, Iso H. Modifying effects of perceived adaptation to shift work on health, wellbeing, and alertness on the job among nuclear power plant operators. Ind Heal. 43:171-8.

[16] Byron K. Meta-analytic Review of Work-Family Conflict and Its Antecedents. J Vocat Behav. 2005;67:119-334.

[17] Schaufeli WB, Bakker AB. Job demands, job resources, and their relationship with burnout and engagement: a multi-sample study. J Organ Behav. 2004;25:293-315.

[18] Bakker AB, Demerouti E. The job demands-resources model: State of the art. J Manag Psychol. 2007;22:309-28.

[19] Makikangas A, Bakker AB, Aunola K, Demerouti E. Job Resources and flow at work: Modelling the relationship via latent growth curve and mixture model methodology. J Occup Psychol. 2010;83:795-814.

[20] Hobfoll SE. Conservation of Resources: A new attempt at conceptualizing stress. Am Psychol. 1989;44:513-24.

[21] Bakker AB. Flow among music teachers and their students: The crossover of peak experiences. J Vocat Behav. 2005;66:26-44.
[22] Harter JK, Schmidt FL, Hayes TL. Business-unit-level relationship between employee satisfaction, employee engagement, and business outcomes: A Meta-analysis. J Appl Psychol. 2002;87(2):26879.

[23] Yeh CM. Tourism involvement, work engagement and job satisfaction among frontline hotel employees. Ann Tour Res. 2013;42:21439 .

[24] Seligman M, Csikszentmihalyi M. Positive psychology: An introduction. Am Psychol. 2000;55:5-14.

[25] Macey WH, Schneider B. The meaning of employee engagement. In: Industrial and Organizational Psychology: Perspectives on Science and Practice. 2008. p. 3-30

[26] Mangi R, Jalbani A. Mediation of Work Engagement between Emotional Exhaustion, Cynicism and Turnover Intentions. Int J Manag Sci BusinessResearch. 2013;2(7):45 - 54.

[27] Hakanen JJ, Bakker AB, Schaufeli W. Burnout and work engagement among teachers. J Sch Psychol. 2006;43:495-513.

[28] Weigl M, Hornung S, Parker SK, Petru R, Glaser J, Angerer P. Work engagement accumulation of task, social, personal resources: A three-wave structural equation model. J Vocat Behav. 2010;77:140-153.

[29] Preacher KJ, Hayes AF. SPSS and SAS Procedures for estimating indirect effect in simple mediation models. Behav Res Methods, Instruments, Comput A J Psychon Soc Inc. 2004;36(4):717-31.

[30] MacKinnon DP, Lockwood CM, Williams J. Confidence limits for the indirect effect: Distribution of the product and resampling methods. Multivariate Behav Res. 2004;39:99-128.

[31] MacKinnon DP. Introduction to Statistical Mediation Analysis. Mahwah, NJ: Lawrence Erlbaum Associates, Inc.; 2008.

[32] Mackinnon DP, Fairchild AJ, Fritz MS. Mediation analysis. Annu Rev Psychol. 2007;58:593-614.

[33] Du Plooy J, Roodt G. Work engagement, burnout and related constructs as predictors of turnover intentions. SA. J Ind Psychol. 2010;36(1):13

[34] Simons JC, Buitendach JH. Psychological capital, work engagement, and organizational commitment amongst call centre employees in South Africa. SA. J Ind Psychol. 2013;39(2):12.

[35] Robyn A, Du Preez R. Intention to quit amongst Generation Y academics in higher education. J Ind Psychol. 2013;39(11):14.

[36] Folkard S. Do permanent night workers show circadian adjustment? A review based on the endogenous melatonin rhythm. Chronobiol Int. 2008;25:215-224.

[37] Kristen S. The relationship between job engagement, work interference with personal life and turnover intention. 2014.

[38] Ram P, Prabhakar GV. The Role of Employee Engagement in Work-related Outcomes. Interdiscip J Res Bus. 2011;1(3):47-61.

[39] Bhatnagar J. Talent management strategy of employee engagement in Indian ITES employees: key to retention. Empl Relations. 2007;29(6):640-663.

[40] Schaufeli WB, Salanova M, Gonza' lez-Roma' V, Bakker AB. The measurement of engagement and burnout: A two sample confirmatory factor analytic approach Studies, . J Happiness. 2002;3:71-92.

[41] Chi CGQ, Qu H. Examining the structural relationships of destination image, tourist satisfaction and destination loyalty: An integrated approach. Tour Manag. 2008;29(4):624-36.

[42] Faullant R, Matzler K, Füller J. The impact of satisfaction and image on loyalty: the case of Alpine ski resorts. Manag Serv Qual. 2008;18(2):163-78.

[43] Tulgan B, Martin CA. Managing Generation Y - Part 2. Business Week Online. 2001 Oct 4;

[44] Martin J. Organizational Behavior and Management. London: Thomson; 2005.

[45] Peterson DK. The Relationship between Ethical Pressure, Relativistic Moral Beliefs and Organizational Commitment. J Manag Psychol. 2003;18(6):557-72.

[46] Havran H, Visser D, Crous F. The internal career orientations of permanent and contracting information technology staff. SA J Ind Psychol Tydskr vir Bedryfsielkd. 2003;29(3):53-60.

[47] Hoffman BJ, Woehr DJ. A quantitative review of the relationship between person-organization fit and behavioral outcomes. J Vocat Behav. 2006;68:389-99.

[48] Coetzee M, Schreuder AMG, Tladinyane R. Career anchors and its relation to organisational commitment. South African Bus Rev. 2007;11(1):65-86. 